\title{
ANALISIS PERLAKUAN AKUNTANSI PAJAK PERTAMBAHAN NILAI (PPN) PADA CV. MULTI DI KOTA MANADO
}

\author{
Marcho Rivelino Tangkere \\ Inggriani Elim \\ Stanley Kho Walandouw \\ Fakultas Ekonomi dan Bisnis, Jurusan Akuntansi \\ Universitas Sam Ratulangi Manado \\ Email : marcho_rivelino@yahoo.co.id
}

\begin{abstract}
ABSTRAK
Pajak merupakan salah satu penerimaan yang sangat potensial dan cukup dominan karena memiliki fungsi budgetair dan mengatur. Perpajakan yang didalamnya terdapat unsur PPN merupakan juga bagian dari kebijakan fiskal pemerintah karena salah satu jenis pajak yang dikenakan oleh pemerintah adalah Pajak Pertambahan Nilai (PPN). Adapun tujuan dari penelitian ini adalah untuk mengetahui perlakuan akuntansi Pajak Pertambahan Nilai yang dilakukan oleh cv. Multi. Berdasarkan hasil penelitian, maka Penerapan Pajak Pertambahan Nilai cv. Multi sudah sesuai Undang - undang No. 42 tahun 2009. Perlakuan akuntansi Pajak Pertambahan Nilai oleh cv. Multi sebagai pengusaha kena pajak sudah sesuai dengan Undang - undang No. 42 Tahun 2009 yaitu sebesar $10 \%$ untuk penyerahan dalam Negeri.
\end{abstract}

Kata Kunci : Perlakuan Akuntansi, PPN.

\begin{abstract}
Lease represent one of the very potential acceptance and dominant enough because owning function of budgetair and arrange. Taxation which in it there are element of Value Added Tax (PPN) represent also the part of fiscal policy of government because one of the Iease type imposed by government is Value added tax ( PPN). As for intention of this research is to know treatment of Value added tax accountancy conducted by cv. Multi. Pursuant to result of research, hence Applying of Value added tax cv. Multi have according to Law No. 42 year 2009. Treatment of Value added tax accountancy by cv. Multi as entrepreneur hit Iease have as according to Law No. 42 Year 2009 that is equal to $10 \%$ for the delivery of home affairs
\end{abstract}

Keywords : Treatment of Accountancy, PPN.

\section{PENDAHULUAN}

\section{Latar Belakang}

Dilihat dari sejarahnya, pajak pertambahan nilai merupakan pengganti dari pajak penjualan. Alasan penggantian ini karena pajak penjualan dirasa sudah tidak lagi memadai untuk menampung kegiatan masyarakat dan belum mencapai sasaran kebutuhan pembangunan, antara lain untuk meningkatkan penerimaan Negara, mendorong ekspor, dan pemerataan pembebanan pajak.Pajak merupakan salah satu penerimaan yang sangat potensial dan cukup dominan karena memiliki fungsi budgetair dan mengatur.

Salah satu jenis pajak yang dikenakan oleh pemerintah adalah Pajak Pertambahan Nilai (PPN) dan Pajak Penjualan atas Barang Mewah (PPnBM).

PPN berbeda dengan PPnBM. Bahkan bisa dikatakan bahwa PPnBM merupakan pajak yang kurang populer dimasyarakat umum. Hal itu bisa disebabkan karena karekter dari PPnBM itu sendiri yaitu; merupakan pungutan tambahan disamping PPN dan hanya dipungut satu kali yaitu pada saat import dan penyerahan oleh Pengusaha Kena Pajak (PKP) pabrikan.

Sesuai dengan tuntutan keadaan saat ini, peraturan perundang - undangan Pajak Pertambahan Nilai dan Pajak Penjualan atas Barang Mewah mengalami perubahan. Pertama - tama PPN mulai diperkenalkan di Indonesia sejak 1 April 1985 untuk menggantikan Pajak Penjualan dengan berlakunya Undang - Undang No. 8 Tahun 1983 tentang Pajak Pertambahan Nilai dan Pajak Penjualan atas Barang Mewah (PPnBM) yang kemudian diubah dengan Undang - Undang No. 11 
Tahun 1994, diubah lagi dengan Undang - Undang No. 18 Tahun 2000 dan terakhir diubah kembali dengan Undang - Undang No. 42 tahun 2009 yang digunakan hingga saat ini sebagai dasar hukum Pajak Pertambahan Nilai dan Pajak atas Barang Mewah.

CV. MULTI sebagai Pengusaha Kena Pajak yang bergerak di bidang penjualan barang tentu melakukan analisis perlakuan Pajak Pertambahan Nilai dalam menjalankan usaha setiap hari, tidak jarang di temukan kekeliruan atau kesalahan dalam analisisnya. Bahkan bukan tidak mungkin apabila analisis perlakuan PPN pada CV. MULTI tidak sesuai dengan Undang - undang PPN yang berlaku saat ini mengingat Undang - undang PPN telah mengalami beberapa kali perubahan.

\section{Tujuan Penelitian}

Tujuan yang hendak dicapai dalam penelitian ini adalah untuk mengetahui apakah penerapan Pajak Pertambahan Nilai (PPN) CV. MULTI sudah sesuai dengan Undang - Undang No. 42 Tahun 2009 serta untuk mengetahui Bagaimana perlakuan akuntansi Pajak Pertambahan Nilai (PPN) oleh CV. MULTI sebagai Pengusaha Kena Pajak.

\section{TINJAUAN PUSTAKA}

\section{Konsep Akuntansi}

Menurut American Accounting Association (AAA), akuntansi adalah proses pengidentifikasian, pengukuran, dan pengkomunikasian informasi ekonomik untuk memungkinkan pembuatan pertimbangan dan keputusan berinformasi oleh pengguna informasi.

\section{Konsep Akuntansi Pajak}

1. Pengertian Akuntansi Pajak

Akuntansi Pajak adalah bidang akuntansi yang berkaitan dengan perhitungan perpajakan, yang mengacu pada peraturan, undang - undang, dan aturan pelaksanaan perpajakan.

\section{Teori Akuntansi Pajak}

Teori Akuntansi Pajak merupakan penalaran logis dalam bentuk seperangkat azas atau prinsip yang dilaakukan dalam ketentuan serta peraturan perpajakan.

\section{Prinsip Akuntansi Pajak}

Prinsip - prinsip yang diakui dalam akuntansi pajak meliputi :

1. Kesatuan akuntansi

2. Kesinambungan

3. Harga pertukaran yang objektif

4. Konsistensi

5. Konservatif

4. Fungsi Akuntansi Pajak

Fungsi Akuntansi Pajak adalah mengola data kuantitatif untuk menyajikan laporan keuangan yang memuat perhitungan perpajakan, yang kemudian akan digunakan sebagai pertimbangan pengambilan keputusan. Tujuan kualitatif dalam akuntansi pajak adalah relevan, dapat dimengerti, daya uji, netral, tepat waktu, daya banding, dan lengkap.

\section{Konsep Perpajakan}

\section{Definisi Pajak}

Menurut Mardiasmo (2009:1) Pajak adalah iuran wajib rakyat kepada kas negara berdasarkan undang - undang (yang dapat dipaksakan) dengan tiada mendapat jasa timbal (kontraprestasi) yang langsung dapat ditunjukkan dan yang digunakan untuk membayar pengeluaran umum.

\section{Fungsi Pajak}

Terdapat dua fungsi pajak yaitu sebagai berikut :

1) Fungsi Budgetair (Sumber Keuangan Negara) yaitu pajak sebagai sumber dana bagi pemerintah untuk membiayai pengeluaran - pengeluarannya.

2) Fungsi Regulerend (Mengatur) yaitu pajak sebagai alat untuk mengatur atau melaksanakan kebijakan pemerintah dalam bidang sosial dan ekonomi.

\section{Sistem Pemungutan Pajak}

Dalam pemungutan pajak terdapat beberapa system pemungutan, yaitu :

1. Official Assessment System 
Sistem pemungutan pajak yang memberikan kewenangan aparatur perpajakan untuk menentukan sendiri jumlah pajak yang terutang setiap tahunnya sesuai dengan ketentuan Undang - Undang perpajakan yang berlaku.

2. Self Assessment System

Sistem pemungutan pajak yang memberikan wewenang wajib pajak untuk menentukan sendiri jumlah pajak yang terutang setiap tahunnya sesuai dengan ketentuan undang - undang perpajakan yang berlaku.

3. With Holding System

Sistem pemungutan pajak yang memberi wewenang kepada pihak ketiga yang ditunjuk untuk menentukan besarnya pajak yang terutang oleh wajib pajak sesuai dengan ketentuan undang - undang perpajakan yang berlaku

\section{Pajak Pertambahan Nilai \\ Dasar Hukum PPN}

Undang - undang yang mengatur pengenaan Pajak Pertambahan Nilai (PPN) dan Pajak Penjualan atas Barang Mewah (PPnBM) adalah Undang - Undang Nomor 8 tahun 1983 tentang Pajak Pertambahan Nilai Barang dan Jasa dan Pajak Penjualan atas Barang Mewah sebagaimana telah beberapa kali diubah terakhir dengan Undang - Undang Nomor 42 Tahun 2009. Undang - undang ini disebut Undang - Undang Pajak Pertambahan Nilai 1984.

\section{Latar Belakang Pajak Pertambahan Nilai}

Adapun latar belakang penggantian tersebut dapat disebutkan sebagai berikut :

1. Dalam pelaksanaan Undang - undang Pajak Penjualan 1951, telah terjadi banyak perubahan fundamental yang bersifat sebagai penyempurnaan maupun tambahan.

2. Mekanisme pemungutan pajak penjualan berdasarkan Undang - undang Pajak Penjualan 1951 dalam pelaksanaannya menimbulkan dampak pengenaan pajak berganda.

3. Undang - undang pajak penjualan 1951 mengandung dualism system pemungutan pajak

4. Sebagai akibat dari pengenaan pajak berganda, maka Pajak Penjualan menjadi tidak netral baik terhadap perdagangan dalam negeri maupun perdagangan internasional

5. Variasi tarif yang cukup banyak, sampai mencapai 9 (Sembilan) macam tarif,

\section{Subjek PPN}

1) Pengusaha Kena Pajak

2) Bukan Pengusaha Kena Pajak

\section{Objek PPN}

1. Penyerahan Barang Kena Pajak yang dilakukan di Daerah Pabean

2. Penyerahan Barang Kena Pajak kepada Pengusaha Kena Pajak yang dilakukan didaerah Pabean dalam lingkungan perusahaan atau pekerjaan oleh pengusaha yang memilih untuk di kukuhkan menjadi pengusaha Kena Pajak.

3. Impor Barang Kena Pajak

4. Penyerahan Jasa Kena Pajak

\section{Saat dan Tempat Terutang Pajak Pertambahan Nilai}

Saat terutangnya PPN sebagaimana ditetapkan dalam Pasal 13 Peraturan Pemerintah Nomor

143 Tahun 2000 Peraturan Pemerintah Nomor 24 Tahun 2004 dan peraturan pelaksanaan lainnya dapat dikelompokkan sebagai berikut :

1. Saat pajak terutang saat penyerahan Barang Kena Pajak berwujud yang menurut sifat atau hukumnya berupa barang bergerak

2. Saat pajak terutang atas penyerahan Barang Kena Pajak berwujud yang menurut sifat atau hukumnya berupa barang tidak bergerak ditentukan oleh salah satu dari perbuatan hukum yang lebih dahulu terjadi

3. Saat pajak terutang atas penyerahan Barang tidak Kena Pajak tidak berwujud

4. Saat pajak terutang atas penyerahan Jasa Kena Pajak

5. Saat pajak terutang atas impor Barang Kena Pajak. Pajak terutang pada saat Barang Kena Pajak dimasukkan kedalam daerah pabean

6. Saat pajak terutang atas ekspor Barang Kena Pajak dikeluarkan dari daerah Pabean.

7. Saat pajak terutang atas pemindahtanganan aktiva yang menurut tujuan semula tidak untuk diperjualbelikan dan persediaan Barang Dagang Kena Pajak yang masih tersisa pada saat pembubaran perusahaan. 
8. Pajak terutang pada saat disepakati atau ditetapkan sesuai hasil Rapat Umum Pemegang Saham

9. Saat pajak terutang peristiwa/perbuatan hukum lainnya

\section{Dasar Pengenaan Pajak}

1. Harga jual

2. Penggantian

3. Nilai Impor

4. Nilai Ekspor

Tarif

5. Nilai lain yang ditetapkan dengan keputusan Menteri Keuangan.

Tarif Pajak Pertambahan Nilai (PPN) yang berlaku saat ini adalah 10\% (sepuluh persen). Sedangkan Tarif PPN sebesar 0\% (nol persen) diterapkan atas :

1) Ekspor BKP Berwujud;

2) Ekspor BKP Tidak Berwujud; dan

3) Ekspor JKP.

\section{Pengkreditan Pajak Masukan}

1. Dasar Hukum

Ketentuan tentang pengkreditan Pajak Masukan diatur dalam Pasal 9 UU PPN 1984, sebelum perubahan dilakukan terhadap UU Nomor 8 Tahun 1983 (UU PPN 1984) oleh UU Nomor 11 Tahun 1994 yang mulai berlaku sejak 1 Januari 1995. Sebagai pelaksanaan Pasal 9 diatur antara lain :

1) Pasal 28 Peraturan Pemerintah Nomor 22 Tahun 1985.

2) Pasal 3 Peraturan Pemerintah Nomor 28 Tahun 1988.

3) Keputusan Menteri Keuangan Nomor 1441/KMK.04/1989 tanggal 29 Desember 1989.

4) Keputusan Menteri Keuangan Nomor 1441a/KMK.04/1989 tanggal 29 Desember 1989.

5) Keputusan Menteri Keuangan Nomor 1441b/KMK.04/1989 tanggal 29 Desember 1989.

6) Keputusan Menteri Keuangan Nomor 296/KMK.04/1994 tanggal 27 Juni 1994.

\section{Pencatatan dan Pembukuan Pajak Pertambahan Nilai}

Dasar hukum untuk pembukuan sebelum 1 Januari 2001 diatur dalam Pasal 6 UU PPN 1984. Dengan UU No. 18 Tahun 2000 dihapus sehingga mengenai kewajiban pembukuan dibidang PPN mengacu pada pasal 28 UU KUP. Penghapusan ini untuk menghindari pengaturan ganda terhadap suatu masalah.

Dalam pasal 1 Angka 26 UU KUP dirumuskan bahwa pembukuan adalah suatu proses pencatatan yang dilakukan secara teratur untuk mengumpulkan data dan informasi keuangan meliputi harta, kewajiban, modal, penghasilan dan biaya, serta jumlah harga perolehan dan penyerahan barang dan jasa, yang ditutup dengan menyusun laporan keuangan berupa neraca dan laporan laba rugi setiap tahun pajak berakhir.

Agar Pajak Pertambahan Nilai dan Pajak Penjualan atas Barang Mewah dapat dihitung dengan benar maka pembukuan harus mencatat juga jumlah harga perolehan atau nilai impor, jumlah harga jual atau nilai ekspor, jumlah harga jual dari barang yang dikenakan Pajak Penjualan atas Barang Mewah, jumlah pembayaran atas pemanfaatan Barang Kena Pajak tidak berwujud dari luar Daerah Pabean. Didalam Daerah Pabean dan atau pemanfaatan Jasa Kena Pajak dari luar Daerah Pabean didalam Daerah Pabean jumlah Pajak Masukan yang dapat dikreditkan dan yang tidak dapat dikreditkan.

\section{Akuntansi Pajak Pertambahan Nilai}

Jika dikaitkan dengan pemenuhan kewajiban PPN. Akuntansi harus dapat memberikan informasi yang diperlukan dalam rangka pemenuhan kewajiban penyelenggaraan pembukuan.

Sedangkan akuntansi PPN adalah akuntansi yang kegiatannya untuk memenuhi kewajiban penyelenggaraan pembukuan dan bertujuan untuk memberikan informasi bagi perusahaan untuk dapat menghitung, membayar, dan melaporkan mengenai PPN dan PPnBM yang terutang.

Prosedur Pencatatan Akuntansi PPN dapat dikelompokkan menjadi :

1. Akuntansi atas PPN Masukan meliputi :

1) Pembelian barang modal/persediaan yang PPN - nya dapat dikreditkan

2) Pembelian atas barang - barang yang PPN - nya tidak dapat dikreditkan 
3) Pembelian yang mendapat potongan harga

4) Jika terjadi retur pembelian.

2. Akuntansi atas PPN Keluaran, meliputi :

1) Prosedur pencatatan penjualan untuk transaksi biasa;

2) Bila terjadi retur penjualan

3) Penjualan dengan uang muka

4) Penjualan Cuma - Cuma/pemakaian sendiri.

\section{Penelitian Terdahulu}

Tabel 2.1. Penelitian Terdahulu

\begin{tabular}{|c|c|c|c|c|c|c|c|}
\hline No. & $\begin{array}{l}\text { Nama } \\
\text { Peneliti/ } \\
\text { Tahun }\end{array}$ & Judul & Tujuan & $\begin{array}{l}\text { Metode } \\
\text { Penelitian }\end{array}$ & $\begin{array}{l}\text { Hasil } \\
\text { Penelitian }\end{array}$ & Persamaan & Perbedaaan \\
\hline 1. & $\begin{array}{l}\text { Liong } \\
\text { Yuk } \\
\text { Hauw } \\
\text { (2009) }\end{array}$ & $\begin{array}{l}\text { Analisis } \\
\text { perhitunga } \\
\text { n,pencatata } \\
\text { n,penyetor } \\
\text { an dan } \\
\text { pelaporan } \\
\text { Pajak } \\
\text { Pertambah } \\
\text { an Nilai } \\
\text { Pada PT. } \\
\text { Yong Maju } \\
\text { Jaya } \\
\text { Lestari }\end{array}$ & $\begin{array}{l}\text { Bertujuan } \\
\text { untuk } \\
\text { mengetahu } \\
\text { i dan } \\
\text { menganalis } \\
\text { is } \\
\text { perhitunga } \\
\text { n, } \\
\text { pencatatan, } \\
\text { penyetoran } \\
\text { dan } \\
\text { pelaporan } \\
\text { Pajak } \\
\text { Pertambah } \\
\text { an Nilai } \\
\text { Pada PT, } \\
\text { Yong Maju } \\
\text { Jaya } \\
\text { Lestari }\end{array}$ & $\begin{array}{l}\text { Deskriptif } \\
\text { kualitatif }\end{array}$ & $\begin{array}{l}\text { Dalam hal } \\
\text { wajib pajak } \\
\text { membetulka } \\
n \text { sendiri } \\
\text { surat } \\
\text { pemberitahu } \\
\text { an yang } \\
\text { mengakibatk } \\
\text { an utang } \\
\text { pajak } \\
\text { menjadi } \\
\text { lebih besar, } \\
\text { maka } \\
\text { kepadanya } \\
\text { dikenakan } \\
\text { sanksi } \\
\text { administrasi } \\
\text { berupa } \\
\text { bunga } \\
\text { sebesar 2\% } \\
\text { sebulan. }\end{array}$ & $\begin{array}{l}\text { Persamaan } \\
\text { yaitu kedua } \\
\text { penelitian } \\
\text { ini sama- } \\
\text { sama } \\
\text { mencatat } \\
\text { pajak } \\
\text { pertambaha } \\
\text { n nilai }\end{array}$ & $\begin{array}{l}\text { Perbedaan yaitu } \\
\text { dalam } \\
\text { penelitian } \\
\text { sebelumnya } \\
\text { membahas } \\
\text { perhitungan, } \\
\text { pencatatan, } \\
\text { penyetoran dan } \\
\text { pelaporan } \\
\text { sedangkan } \\
\text { dalam } \\
\text { penelitian ini } \\
\text { hanya } \\
\text { membahas } \\
\text { perhitungan dan } \\
\text { pencatatan. }\end{array}$ \\
\hline
\end{tabular}

Sumber : Data Olahan 2014 


\section{METODE PENELITIAN}

\section{Jenis Penelitian}

Jenis penelitian yang digunakan penulis adalah penelitian deskriptif, yang dilakukan dengan cara mengumpulkan data yang berhubungan dengan permasalahan yang dihadapi. Data merupakan keterangan - keterangan yang diperoleh dari penelitian atau melalui referensi - referensi untuk dapat digunakan dalam menganalisa Perlakuan Akuntansi Pajak Pertambahan Nilai (PPN) Pada CV. MULTI serta untu mengetahui apakahpenerapan Pajak Pertambahan Nilai (PPN) CV. MULTI sudah sesuai dengan Undang - Undang No. 42 Tahun 2009.

\section{Prosedur Peneltian}

Prosedur penelitian adalah langkah - langkah yang digunakan sebagai alat untuk mengumpulkan langkah dan menjawab pertanyaan - pertanyaan dalam penelitian. Langkah - langkah tersebut yaitu :

1. Mengumpulkan teori - teori yang relevan dengan Analisis perlakuan akuntansi pajak pertambahan nilai serta teori- teori mengenai akuntansi Pajak Pertambahan Nilai

2. Memilih prosedur serta teknik yang digunakan

3. Mencari data yang akan digunakan

4. Memberikan kesimpulan serta saran yang dapat menjadi masukan bagi pihak CV. MULTI.

\section{Objek Penelitian}

Objek penelitian adalah Perlakuan Akuntansi Pajak Pertambahan Nilai Pada CV. MULTI di Kota Manado.

\section{Metode Pengumpulan Data}

\section{Jenis Data}

Data adalah sekumpulan informasi yang diperlukan untuk pengambilan keputusan.

1) Data Kualitatifyaitu data yang berisi tentang sejarah singkat perusahaan, visi, misi, struktur organisasi CV. MULTI di Kota Manado serta dengan membandingkan data - data dengan teori yang berlaku dari buku - buku referensi dan perkuliahan.

2) Data Kuantitatifyaitu data berupa angka - angka seperti data transaksi CV. MULTI di Kota Manado.

\section{Sumber Data}

1) Data Primer, yaitu data penelitian yang diperoleh secara langsung dari sumber data asli, data primer dalam penelitian ini adalah data yang dikumpulkan, diolah dan diperoleh langsung dari CV. MULTI di Kota Manado berupa data - data transaksi.

2) Data Sekunder, yaitu data - data yang diperoleh secara tidak langsung melalui media media, seperti buku - buku, artikel maupun jurnal, Undang - undang perpajakan dan sumber data lainnya yang ada hubungannya dengan penelitian yang dipilih penulis untuk memberikan landasan teori yang kuat dalam penulisan laporan skripsi ini.

\section{Teknik Pengumpulan Data}

Teknik pengumpulan data dilakukan dengan cara sebagai berikut :

1. Penelitian Lapangan

Penelitian ini dilakukan di tempat penelitian study kasus dengan cara :

1) Wawancara yaitu melakukan tanya jawab dengan pihak - pihak yang bersangkutan untuk mendapatkan gambaran yang jelas mengenai perusahaan tersebut.

2) Observasi atas dokumen - dokumen berupa data transaksi

2. Penelitian kepustakaan, dimana dalam penelitian ini diperoleh data ilmiah yang bersifat teoritis dan literatur dan buku yang berhubungan dengan pembahasan ini. Informasi ini digunakan sebagai landasan teori untuk menganalisa.

\section{Metode Analisis}

Metode analisis yang digunakan penulis adalah analisa deskriptif kualitatif. Dalam analisis ini, analisis dilakukan dengan menghasilkan laporan penelitian yang lebih luas dengan cara menginterprestasikan data yang telah dianalisis tersebut dihubungkan dengan teori yang ada untuk kemudian diambil suatu keputusan. 


\section{HASIL PENELITIAN DAN PEMBAHASAN}

\section{Gambaran Umum Perusahaan \\ Profil Perusahaan}

CV. MULTI merupakan perusahaan yang bergerak di bidang usaha dagang elektronik. Terletak di Jl. Sam Ratulang Manado dengan Luas Tanah 25 Meter x 16 Meter.

\section{Sejarah Singkat Perusahaan}

CV. MULTI didirikan berdasarkan Akta No. 19 tanggal 20 Maret 1997 dari Oky Annette Kahimpong., SH, Notaris di Manado. Jumlah karyawan yang telah direkrut oleh CV. MULTI sampai tahun 2013 adalah sebanyak 10 karyawan dengan berlatar belakang pendidikan yang beragam.

\section{Hasil Penelitian}

Akuntansi PPN berkaitan erat dengan pembuatan faktur pajak standar, secara yuridis PPN terutang pada saat penyerahan BKP dan atau JKP tetap secara praktis PPN terutang pada saat faktur pajak dibuat.

Di bawah ini adalah beberapa contoh pencatatan transaksi - transaksi yang mungkin terjadi dalam pelaksanaan akuntansi PPN :

1. Pencatatan atas transaksi pembelian (PPN Masukan) yang PPN - nya dapat Dikreditkan Contoh : CV. MULTI membeli barang untuk persediaan dalam bulan Agustus 2012 seharga Rp. 20.000.000, dengan kredit dari PT. TSU.

Jurnal :

Pembelian barang dagangan $\quad$ Rp. 20.000 .000

PPN Masukan

Rp. 2.000 .000

Hutang Dagang

Rp. 22.000 .000

2. Pencatatan atas transaksi pembelian (PPN Masukan) yang PPN - nya dapat dikreditkan.

Contoh : Pembayaran angkutan atas pembelian barang sebesar Rp. 1.100.000, pembayaran sudah termasuk PPN $10 \%$

Jurnal :

$\begin{array}{lr}\text { Biaya angkutan } & \text { Rp. } 1.000 .000 \\ \text { PPN Masukan } & \text { Rp. } 100.000\end{array}$

Kas Rp. 1.100 .000

3. Pencatatan transaksi penjualan (PPN Keluaran).

Contoh : Jika transaksi penjualan di atas dilakukan secara tunai (kas) atau dalam hal ini penerimaan pembayaran dilakukan sebelum penyerahan BKP atau JKP atau pada saat PKP rekanan menyampaikan tagihan kepada pemungut PPN, maka Faktur Pajak harus diterbitkan pada saat pembayaran.

Jurnal :

Kas/Bank Rp. 11.000 .000

Penjualan Rp. 10.000 .000

PPN Keluaran Rp. 1.000 .000

4. Jurnal untuk mencatat PPN Terutang

Apabila PPN Keluaran lebih besar dari PPN Masukan maka terdapat PPN yang masih harus dibayar.

Jurnal :

PPN

$\mathrm{XXX}$

Kas $\quad \mathrm{xxx}$

\section{Pembahasan}

Penerapan Pajak Pertambahan Nilai CV MULTI sudah sesuai Undang - undang No. 42 tahun 2009. Berdasarkan Undang - undang No. 42 Tahun 2009, Pajak Pertambahan Nilai (PPN) adalah Pajak tidak langsung atau konsumsi dalam negeri yang dikenakan atas setiap tingkat penyerahan Barang Kena Pajak atau Jasa Kena Pajak oleh Pengusaha Kena Pajak. Di dalam perhitungan PPN berdasarkan Pasal 9 ayat (2), Undang - undang No. 42 tahun 2009, terdapat dua metode, yaitu :

1. Pajak keluaran adalah PPN yang dipungut oleh Pengusaha Kena Pajak (PKP) pada waktu penyerahan BKP atau JKP. 
2. Pajak Masukan adalah PPN yang dibayar oleh Pengusaha Kena Pajak pada waktu pembelian BKP, penerimaan JKP atau impor JKP.

Di dalam pencatatan PPN CV. MULTI, nilai PPN Keluaran diperoleh dari nilai barang yang dijual dikalikan dengan dasar tarif PPN sebesar 10\%. Dasar perkalian ini sudah sesuai dengan yang ditetapkan Undang - undang No. 42 tahun 2009.

Di samping pemungutan PPN Keluaran, CV. MULTI melakukan pembayaran PPN Masukan atas pembelian barang - barang dan pengeluaran lainnya. Pembayaran PPN Masukan dilakukan berdasarkan kegiatan usaha CV. MULTI dengan Pengusaha Pajak lainnya. Pajak masukan juga dikenakan berdasarkan tarif yang berlaku sesuai Undang - undang No. 42 tahun 2009. PPN Masukan dapat dikreditkan berdasarkan masa pajak yang sama.

Apabila PPN Keluaran lebih besar dari PPN Masukan maka selisihnya yaitu PPN Keluaran dikurangi PPN Masukan harus disetorkan ke kas Negara. Apabila sebaliknya PPN Keluaran lebih kecil dari PPN Masukan maka selisihnya bisa dikompensasikan ke bulan berikutnya.

\section{Kesimpulan}

\section{PENUTUP}

Berdasarkan hasil penelitian dan pembahasan yang telah dikemukakan sebelumnya, penulis dapat membuat kesimpulan sebagai berikut :

1. Perlakuan akuntansi CV. MULTI sudah sesuai dengan Undang - Undang No. 42 tahun 2009.

2. Perhitungan Pajak Pertambahan Nilai serta Penerapan Pajak Pertambahan Nilai oleh CV. MULTI sebagai Pengusaha Kena Pajak sudah sesuai dengan Undang - Undang No. 42 tahun Saran 2009 yaitu sebesar 10 (sepuluh) persen untuk penyerahan dalam negeri.

Menurut penulis tentang apa yang telah dilakukan perusahaan berkenaan dengan Pelaksanaan Pajak Pertambahan Nilai sudah benar dan sesuai dengan Undang - undang yang berlaku.

Akan tetapi untuk masa yang akan datang sebaiknya memberikan kesempatan kepada sumber daya manusia yang ada untuk mengikuti Pelatihan pada Lembaga Pendidikan untuk menambah pengetahuan di bidang Akuntansi dan Perpajakan, agar dapat mengikuti perkembangan peraturan peraturan yang berlaku.

\section{DAFTAR PUSTAKA}

IKAPI. 2013. Undang - Undang PPnBM. Fokusmedia. Bandung.

Ikhsan dan Suprasto. 2008. Teori Akuntansi \& Riset Multiparadigma. Graha Ilmu. Yogyakarta.

Jusup Haryono. 2005. Dasar - dasar Akuntansi. Bagian Penerbitan Sekolah

Tinggi Ilmu Ekonomi YKPN. Yogyakarta.

Kuncoro Mudrajad. 2009. Metode Riset untuk Bisnis \& Ekonomi. Erlangga.

Jakarta.

Mardiasmo, 2009. Perpajakan. C.V Andi Offset. Yogyakarta.

Mardiasmo. 2011. Perpajakan. C.V Andi Offset. Yogyakarta.

Muljono Djoko, 2010. Panduan Brevet Pajak. C.V Andi Offset. Yogyakarta.

Smith Eddy. 2005. Kamus Akuntansi. Prestasi Pustaka. Jakarta.

Yamin Mohammad. 2012. Pajak Pertambahan Nilai. Graha Ilmu. Yogyakarta. 